\title{
The genetics of developmental dyslexia
}

\author{
Julie Williams $^{*}{ }^{1}$ and Michael C O'Donovan ${ }^{1}$ \\ ${ }^{1}$ Department of Psychological Medicine, Cardiff University, Henry Wellcome Building, Heath Park, \\ Cardiff CF14 4 XN, UK
}

\begin{abstract}
Reading reflects the complex integration of several cognitive processes and proves more difficult to achieve for a significant proportion of the population. Developmental dyslexia (DD), or specific reading disability, is influenced by genes, a fact that has led several research groups to attempt to identify susceptibility genes through the sequential analysis of genetic linkage and association. Strong evidence has now emerged for the presence of genes influencing DD at several chromosomal loci and for at least one of these, there is evidence implicating specific genes. In this review, we present the evidence for a genetic contribution to DD and its component processes and review the current status of molecular genetic research aimed at identifying susceptibility genes for this common, complex disorder. European Journal of Human Genetics (2006) 14, 681-689. doi:10.1038/sj.ejhg.5201575
\end{abstract}

Keywords: developmental dyslexia; genetics; review

\begin{abstract}
Introduction
Developmental dyslexia (DD) or specific reading disability (SRD) is identified by a gross difficulty in reading and writing, which is not attributable to a general intellectual or sensory impairment or to a lack of exposure to an appropriate educational environment. There are no universally accepted thresholds or operational definitions for categorising an individual as having DD. However, most studies define DD as a deficit in reading age of 2 years or greater compared to that predicted from chronological age. While DD is multifactorial, as we shall see, a major source of variation in risk is genetic. This observation has spawned a considerable amount of molecular genetic research into DD predicated upon the hope that the identification of susceptibility genes will provide valuable insights into the biological basis of this common disorder, thereby providing a platform for future therapeutic interventions, and a greater understanding of the complex cognitive processes
\end{abstract}

*Correspondence: Professor J Williams, Department of Psychological Medicine, Cardiff University, Henry Wellcome Building, Heath Park, Cardiff CF14 4XN, UK. Tel: + 44292074 3247; Fax: + 44292074 7839; E-mail: williamsj@cardiff.ac.uk

Received 12 August 2005; revised 23 November 2005; accepted 25 November 2005 that contribute to reading, and also to other cognitive functions.

The task of reading requires the integration of different but complementary cognitive processes. Most evidence suggests that deficits in phonological processing are central to the development of DD. ${ }^{1}$ The basic unit of phonological processing is the phoneme, the smallest discernible segment of speech. Phonological processing encompasses phoneme awareness, decoding, storage and retrieval. Another component of the reading process is orthographic processing of the visual appearance or shape of a written word. $^{2}$ The speed at which language-based information is processed may also be of importance. ${ }^{3}$ It is unclear to what extent each of these components of reading ability is the result of common or independent functional processes. However, many genetic studies have sought to dissect the global DD phenotype by investigating each separately, as well as using global measures of general reading ability. ${ }^{4-8}$ In addition, researchers have employed different approaches to the concept of DD. Some view DD as the extreme end of a spectrum of reading ability and have hence used continuous measures of ability. Others have taken a categorical approach to defining DD, entertaining the possibility that DD may be qualitatively different to reading ability and that the route to DD may be along 
specific causal pathways that do not influence ability in the normal range. It is ofcourse feasible that some susceptibility genes could affect reading ability throughout its observable range, while others may only affect the extremes of reading disability.

\section{Family studies}

Hinshelwood $^{9}$ in 1907 first documented the tendency for DD to cluster in families. Numerous studies since have supported this observation. ${ }^{10-13}$ In an early family study of DD, Rutter and co-workers ${ }^{12}$ observed that $34 \%$ of children with DD had a parent or sibling with a reading problem compared to $9 \%$ of control children. Four of the major family studies undertaken have reported consistently high sibling recurrence risks of $40.8 \%$ $\left(N=174^{10}\right), 42.5 \%\left(N=40^{14}\right), 43 \%\left(N=168^{15}\right)$ and $38.5 \%$ $\left(N=52^{16}\right)$, compared with estimates of the population frequency of DD, which range between 5 and $10 \% .{ }^{17}$ Thus, the relative risk for DD in first degree relatives is between 4 and 10.

\section{Twin studies}

Early twin studies of DD showed significantly greater monozygotic (MZ) than dizygotic (DZ) concordance for DD, but most suffered methodological problems, especially ascertainment bias and the inconsistent use of operational definitions of DD. ${ }^{18,19}$ The first compelling evidence that the high familiality of DD was due to genetic rather than shared environmental factors, came in the 1980s with the publication of two key twin studies; the Colorado Twin Reading Study ${ }^{20}$ and the London Twin Study. ${ }^{21}$ Subjects in the Colorado study ( $\mathrm{MZ}=64 ; \mathrm{DZ}=55$ pairs) were ascertained on the basis that at least one member of the twin pair had reading disability. The London study took a different approach by sampling 285 twin pairs from the general population. ${ }^{21}$ The twins thus identified allowed the London study to investigate influences across the full range of reading and spelling ability rather than reading disability alone. Despite the different approaches, there was convergent evidence that reading and spelling abilities are highly heritable.

The Colorado Study found a high proportion of the population variance in risk was attributable to genes for deficits in reading (heritability $=44 \%)$ and spelling $(62 \%)$ was attributable to genes. Moreover, examining the components of DD, the genetic contribution was higher to deficits in phonological processing as indicated by nonword reading $(75 \%)$ than to orthographic processing (31\%). The London Twin Study found strong evidence for the heritability of spelling (75\%, I.Q. controlled) and moderate evidence for reading ability (44\%).

In a series of further publications, Olson et $a l^{2}$ extended their analysis of phonological and orthographic dimensions within the Colorado Twin Study. ${ }^{22}$ Contrary to their initial findings, they observed significant heritability for orthographic processing (56\%), which was approximately the same as that observed for phonological processing (59\%).

The concept of heritability is not a fixed one since the proportion of the total variance attributable to genes is partly dependent on the variance in exposure to the relevant (but unknown) environmental risk factors and on the characteristics of the population studied. In a further analysis of the Colorado data set, DeFries et $a l^{23}$ showed that reading had a higher heritability in younger compared with older children, whereas the heritability of spelling although observed across all ages, actually increased with age. Again, using the Colorado twin study, Wadsworth et $a^{24}$ found significantly greater heritabilities for children with ence $(43 \%)$, indicating that environmental factors play a greater role in reading difficulties experienced by children with a lower IQ.

Hohnen and Stevenson ${ }^{25}$ demonstrated that the genes influencing general intelligence and also general language ability were also relevant to early variation in reading ability. Recently, Tiu et $a l^{26}$ modelled the relationship between phoneme awareness, naming speed, IQ and reading performance and found evidence that phonological processing and naming speed, as well as IQ, contribute to reading disability.

There is some evidence for gender-specific genetic influences upon risk. ${ }^{27,28}$ Thus, Knopnik et $a l^{27}$ found the genetic correlation between the sexes for reading performance was significantly less than 1 , which suggests the existence of gender-specific risk alleles or at the very least gender-specific genetic effect sizes. This may contribute to the increased ratio of 2:1 of DD observed in males, which recent evidence suggests is not due to ascertainment bias, as originally thought. ${ }^{29}$

There has also been interest in the genetic relationships between DD and other common childhood disorders. These include attention deficit hyperactivity disorder (ADHD), specific language impairment, speech-sound disorder, dyspraxia and dyscalculia. Although a review of these areas is beyond the scope of this paper, there is growing evidence of complex relationships in which a number of genes may affect susceptibility to more than one of these disorders. ${ }^{30}$

\section{Molecular genetics}

Currently, the Human Gene Nomenclature Committee (http://www.gene.ucl.ac.uk/nomenclature/) has designated nine dyslexia susceptibility loci (DYX1 to DYX9), which comprise DYX1, 15q21; DYX2, 6p21; DYX3, 2p16-p15; DYX4, 6q13-q16; DYX5, 3p12-q12; DYX6, 18p11; DYX7, 11p15; DYX8, 1p34-p36; and 
DYX9, Xp27 (see Figure 1 for summary). We would stress that this should not be taken to indicate that the evidence for all loci is definitive, or that this represents a complete catalogue of the map positions of all dyslexia genes.

\section{DYX1}

Smith et $^{31}$ were the first to report evidence for a DD locus on chromosome 15 based upon linkage to chromosome heteromorphisms (LOD score = 3.2). In 1997, Grigorenko et $a l^{4}$ reported significant evidence of linkage (LOD
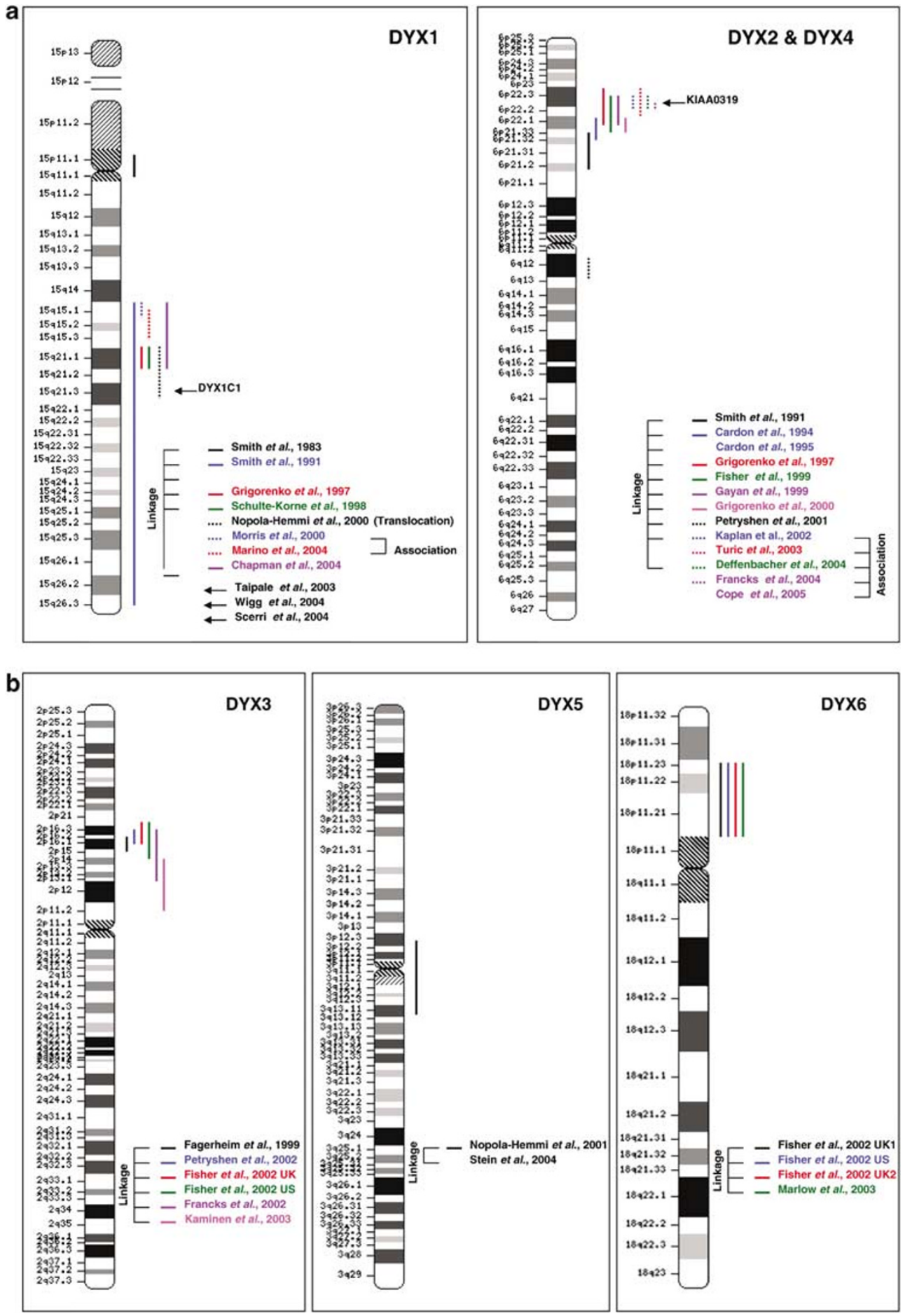

Figure 1 (a-c) Summary of chromosomal loci showing evidence for susceptibility genes for developmental dyslexia. 

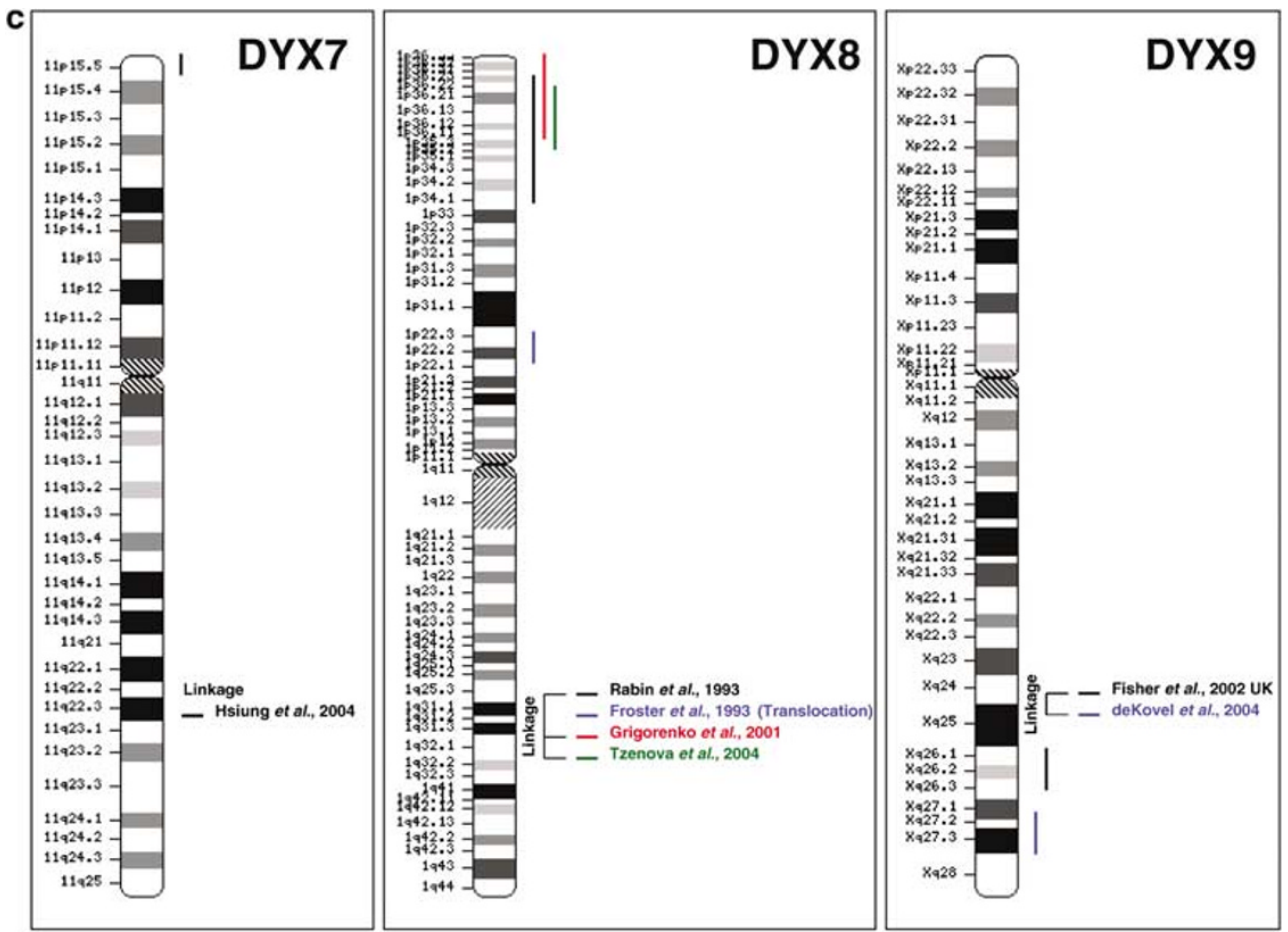

Figure 1 continued.

score $=3.15$ ) to single-word reading in six extended families, each of which contained four individuals with a significant degree of reading disability. No significant linkage was observed with phonological phenotypes, although phonological awareness was found to be linked to chromosome 6 in the same families. Schulte-Körne and co-workers ${ }^{32,33}$ also reported suggestive evidence of linkage (maximum LOD score $=1.78$ ) to chromosome 15 for spelling disability in seven multiplex families. Further evidence was provided by Chapman et al, ${ }^{34}$ who observed suggestive evidence of linkage (single point $\mathrm{LOD}=2.34$, subset of 111 pedigrees), with phenotypes characterized by phonological decoding and single word reading. Interestingly, given reports of comorbidity between the two disorders, the LOD score maximized within $10 \mathrm{cM}$ of a region reportedly linked to $\mathrm{ADHD} .^{35}$

Morris et $\mathrm{al}^{36}$ followed up the earlier linkage reports by undertaking a two-stage, family-based, linkage disequilibrium mapping study. Replicated evidence for association was found in each sample, with maximal evidence for marker D15S944, which is located within the phopholipase $\mathrm{c} \beta 2$ gene (PLCB2). Using a combination of direct and indirect association strategies, Morris et $\mathrm{al}^{37}$ screened this and a second phospholipase gene (A2, Group IVB, cystosolic; PLAZG4B) mapping to the same region, in the same samples, with intergenic markers spaced a maximum of $6 \mathrm{~kb}$. Neither showed evidence of association with DD. Marino et $\mathrm{al}^{38}$ have also found evidence of association to microsatellites on 15q.
Using an approach that exploits chromosomal abnormalities, Taipale et $a l^{39}$ reported the cloning of a chromosome $15 \mathrm{q}$ breakpoint in a family in which a $t(2 ; 15)$ (q11;q21) translocation co-segregated with reading disability. The translocation disrupted a gene EKN1, now known as dyslexia susceptibility 1 candidate 1 (DYX1C1), which mapped some $15 \mathrm{Mb}$ from the signal reported by Morris et $a l .{ }^{37}$ In the same study, Taipale et $a l^{39}$ reported evidence for association between DD and a $-3 \mathrm{G}>\mathrm{A}$ SNP located three bases $5^{\prime}$ to the ATG translational start site that disrupts three predicted transcription factor binding sites and also a $1249 \mathrm{G}>\mathrm{T}$ SNP that introduces a stop codon and is predicted to encode a protein truncated by four amino acids. Four studies have subsequently failed to replicate the specific associations with these putative functional variants. ${ }^{40-43}$ However, evidence for association with different alleles and/or haplotypes was observed in two of these studies. ${ }^{40,42}$ Although, the status of this gene is unclear, it is clear that the functional variants are not to be those originally described. ${ }^{39}$

\section{DYX2}

Cardon et $a l^{45,46}$ and Smith et al ${ }^{44}$ first detected significant linkage to chromosome $6 \mathrm{p} 21.3$ in samples of sibling pairs and of DZ twins from the Colorado Twin Register. The phenotype was a quantitative variable derived from a composite of reading ability scores. Subsequently, Grigorenko et $a l^{4,5}$ also reported significant linkage to this region 
using eight large multiplex families. Their earlier study ${ }^{4}$ suggested the locus might particularly influence a phenotype characterized as phonemic awareness, although significant linkage was also observed with phonological decoding and single-word reading. However, this pattern was not confirmed in their extended study ${ }^{5}$ in which linkage was found to single-word reading, vocabulary and spelling, with phonemic awareness and phonological decoding showing little evidence.

Subsequently, evidence for linkage to $6 \mathrm{p} 23.3$ has emerged from others for both orthographic and phonological measures (Fisher et al, ${ }^{7}$ extended by Marlow et al ${ }^{47}$ and Gayan et $a l^{8}$ ). Fisher et $\mathrm{al}^{7}$ observed significant linkage in a UK sample of 180 sibling pairs $(P=0.004)$ and Gayan in 79 sibships from an extension of the Colorado data set. Studies of extended versions of both these data sets subjected to a whole-genome scan for QTL's reported strong evidence for linkage to $6 \mathrm{p}$ in the UK sample (phonological decoding two-point $P=0.00001$ ) but slightly weaker evidence in the US sample (phonological decoding, two-point $=0.002^{6}$ ). One sample failed to show evidence for linkage to this region in their sample, ${ }^{48,49}$ and a second shows only a weak signal in this region $\left(\mathrm{LOD}=0.5^{34}\right)$. Petryshen et $a l^{49}$ have speculated that their failure to detect linkage to $6 \mathrm{p} 23$ in their families may reflect locus heterogeneity related to DD subtypes. Whether this is the case or whether it is related to low power in the context of small to moderate genetic effect sizes, or indeed locus heterogeneity not specifically related to phenotypic selection, remains to be seen. Nevertheless, for what is a complex phenotype, the evidence for linkage between DD and $6 \mathrm{p} 23$ is strong and surprisingly well replicated.

Turic et $a l^{50}$ followed up the linkage findings by targeting a region they considered to show most overlap between the studies for linkage disequilibrium analysis using a panel of microsatellites spaced every $1 \mathrm{Mb}$ or so. Although not a dense map by today's standards, they did identify a region between D6S109 and D6S260 that showed significant evidence for haplotype association with DD in two independent samples of parent-proband trios. Moderate evidence of association was also observed at locus D6S258.

Five recent gene based association studies within the region of maximum linkage on $6 \mathrm{p}^{51-55}$ have attempted to further refine the evidence of association within this region. Deffenbacher et $a l^{51}$ first refined their region of linkage in the Colorado sample to a $3.24 \mathrm{Mb}$ region. Of the 12 genes within this region, 10 were tested by indirect association methods using a low-density panel of 31 singlenucleotide polymorphisms (SNP) markers. Significant associations were detected in at least one of five of components of DD tested for five of the 10 genes: VMP $(P=0.05-0.004), \quad$ DCDC2 $\quad(P=0.05-0.001), \quad$ KIAA0319 $(P=0.03)$, TTRAP $(P=0.03-0.008)$ and THEM $2(P=0.008)$.
Francks et $a l^{52}$ also used the Colorado sample, together with an independent series of UK sibships with at least one DD sibling. First, they refined the linked region (IQ adjusted), to $5.8 \mathrm{Mb}(\mathrm{LOD}=3.48)$. Of the 80 genes in this region, 40 encoded histone proteins and were discarded. Eight of the remaining genes were brain expressed and were tested for association, these comprised ALDH5A1, KIAA0319, TTRAP, THEM2, C6 orf32, SCGN, BTN3A7 and BTN2A7. Initially, 15 SNPs were tested in a sample of 89 UK families, and the region surrounding one positive SNP was typed at higher density with an additional 42 markers. This revealed evidence of association to a number of SNPs, which were typed in an independent set of 175 families. Stronger evidence was obtained for a more severe phenotype. Evidence for association was also obtained in the Colorado sample; again this became stronger when the sample was selected for a more extreme phenotype. Taking all data together, the study suggested the presence of a DD susceptibility gene within a 77-kb region spanning TTRAP and the first four exons of KIAA0319.

Cope et $a l^{41}$ also undertook an association analysis of genes in this region with a dense marker grid (one every $2 \mathrm{~kb}$ across each gene; with the exception of large intronic regions in DCDC2). Subjects were from the UK (223 DD cases, 273 controls, 143 trios) and represented a fairly severe extreme of the DD spectrum. Analysis of markers in pooled samples of cases and controls provided multiple signals in KIAA0319, which were later genotyped individually in the case-control sample and in a sample of parent-proband trios. Nominally significant findings were also obtained in MRSL2 and in THEM2. Thus, these three studies obtained some support for association to KIAA0319. Although an association originating in an adjacent gene cannot be excluded, the signal in the study of Cope et al $^{53}$ could best be attributed to KIAA0319 gene, a haplotype of which showed highly significant association (global $P=0.00001$ ).

One of the associated SNPs giving the strongest evidence for association in KIAA0319 is rs4504469, a nonsynonymous SNP in exon 4, which is predicted to affect glycosylation of the encoded protein. Six of the significant SNPs from the study of Cope et al ${ }^{53}$ including rs4504469 showed the same pattern of association in the UK sample studied by Francks et al. ${ }^{52}$ However, as rs4504469 did not appear associated in their Colorado sample, it is unlikely to be the functional variant per se. Interestingly, marker JA04, a microsatellite that was previously associated with orthographic choice $(P=0.003)$ in a subsample of the Colorado families ${ }^{56}$ is now known to be located within KIAA0319. In the sample of Cope et $a,^{53}{ }^{3 A 04}$ is in strong linkage disequilibrium with the associated SNPs (rs4504469: $D^{\prime}=0.71$, rs6935076: $D^{\prime}=1$; unpublished data). Thus, at least three independent samples, ${ }^{56}$ Francks et $a l^{52}$ (UK sample), Cope et $a l^{41}$ and two other samples that in part may overlap with that used by Kaplan and co-workers ${ }^{56}$ 
(Deffenbacher et $a ;^{51}$ Francks et $a l ;^{52}$ US sample) now provide evidence for association between variation in or around KIAA0319 and DD. How variation in the KIAA0319 gene might play a role in DD is unknown as indeed is the function of this gene. The presence of a number of predicted protein sequence domains suggests it might play a role in cell-cell adhesion thus influencing neuronal connectivity and possibly migration.

Recently, Meng et $a l^{54}$ and Schumacher et $a l^{55}$ produced evidence implicating the DCDC2 gene within the linked region on 6p. Meng and co-workers genotyped 147 SNPs in a proportion of the Colorado sample, in the same region studied by Deffenbacher and co-workers and found evidence of association with one or more of 12 quantitative DD phenotypes. Although evidence of association was found widely across the region, including nominally significant findings in KIAA0319, the strongest evidence was found with the DCDC2 and, in particular, a composite signal resulting from collapsing a deletion within intron 2 and rare alleles of a repeat polymorphism present within the deleted region into a single 'pseudo-allele' The function of DCDC2, standing for doublecortin domain containing 2 , the doublecortins domains were first described in the context of the doublecortin gene, which is involved in directing neuronal migration. It also appears from manipulations to reduce DCDC2 expression that this gene may also be involved in neuronal migration. ${ }^{59}$ Schumacher and co-workers have also tested association between variation spanning the DCDC2 and KIAA0319 gene region and found evidence of association with extreme spelling disability in two SNP's in DCDC2, which replicated only with extreme spelling disability in a Finnish sample. The possibility that two DD susceptibility genes reside in this region might be entertained, especially in the light of the similar putative functions in neuronal migration, predicted for both the KIAA0319 and DCDC2 genes.

\section{DYX3}

A genome scan by Faggerheim et $a l^{57}$ based on a single family of Norwegian descent with a high density of affecteds, provided the first evidence for linkage to chromosome 2p15-16. Initial results showed modest evidence of linkage $(\mathrm{LOD}=0.80)$ to $2 \mathrm{p}$, but when additional markers were added, much stronger evidence emerged (two point parametric $\mathrm{LOD}=2.9-4.3$, multipoint nonparametric NPL $P=0.02-0.0009)$. Petryshen et al ${ }^{58}$ attempted to replicate this linkage in their sample of 96 Canadian families, ${ }^{58,59}$ using categorical and quantitative definitions of DD based upon reading history (adults) or performance measures of phonological processing and spelling. Evidence of linkage within the DYX3 region was detected using nonparametric analysis for DD as a categorical trait $(P=0.009)$ and variance components analysis for DD as a QTL (peak LOD scores: spelling $=3.82$ phonological coding $=1.13$ ).
Two other independent samples have subsequently supported linkage to the DYX3 region ${ }^{6,60}$ (US: multipoint $P=0.001$ for phonological awareness; UK: little evidence with multipoint analysis, two-point: $P=0.0007$ for orthographic choice). Fine mapping of this region in the US sample ${ }^{60}$ narrowed it to $12 \mathrm{cM}(61-75 \mathrm{Mb})$. Finally, a Finnish sample of 11 extended families segregating DD showed evidence for linkage was observed on $2 p$ centromeric to the original region ${ }^{57,61,62}$ (DD defined categorically; $\mathrm{NPL}=3, P=0.001 ; 78 \mathrm{Mb}$ ). While this may represent a different locus, nominally significant evidence for linkage was obtained with markers from $72-88 \mathrm{Mb}$, and there was some positive signal from 53-132 Mb. Imprecision is a known consequence of linkage analyses in complex traits. In our view, there is strong evidence for at least one susceptibility gene on $2 p$, but it is as yet unclear that the evidence forces the conclusion of two loci.

\section{DYX4}

In 2001, Petryshen et $a l^{63}$ observed suggestive evidence of linkage to chromosome $6 \mathrm{q}$ in their sample of 100 affected sibling pairs (multipoint NPL $P=0.02-0.0005$ for a range of sub components of DD). This has yet to be replicated in other samples.

\section{DYX5}

Nopola-Hemmi et al ${ }^{64,65}$ reported significant linkage (dominant model, categorical phenotype, $L O D=3.84$ at $3 \mathrm{p} 12-\mathrm{q} 13)$ in a Finnish family segregating DD (74 individuals; 21 with DD). Recently, this region has shown evidence for linkage to speech-sound disorder, which shares deficits in phonological processing with DD. ${ }^{66}$ In that study, the multipoint LOD for phonological memory maximized at $84 \mathrm{Mb} \quad(P=0.0006)$, supporting earlier observations that susceptibility genes for DD may also affect other related disorders.

\section{DYX6}

The first whole-genome scan for quantitative traits influencing DD, yielded its strongest linkage signal at $18 \mathrm{p} 11.2$ in two samples (UK: single word reading $P=0.00001 ; \mathrm{US}$ : $P=0.004$ ), which was further supported in a third (UK: phoneme awareness $P=0.00004)$. A subsequent multivariate analysis of six quantitative traits based on the UK sample showed relationships with a range of reading measures in this region, ${ }^{47}$ all of which appeared to contribute to the linkage. A direct attempt to replicate this linkage by Chapman et $a l^{34}$ and Schumacher et $a l^{67}$ failed to show evidence in their sample, but nevertheless, the region remains a strong region of interest for DD. 


\section{DYX7}

Exploiting postulated overlapping aetiologies of DD and ADHD, Hsiung et al ${ }^{68}$ tested for linkage to DD in a region of chromosome 11 containing DRD4 (dopamine receptor D4), which is the best replicated susceptibility gene for ADHD. They did observe evidence for linkage (multipoint MFLOD $=3.57, \quad P=0.00005$ between DRD4 and HRAS) and excess transmissions of the ADHD risk allele, which fell just short of significance $(P=0.06)$. The data thus broadly support the hypothesis of a locus for DD in or around DRD4, although it should be noted that the authors did not take account of ADHD within their sample and it is therefore unclear whether the evidence stems from those with ADHD and DD traits or from the DD sample as a whole. Given the strength of evidence supporting DRD4 in $\mathrm{ADHD}$, it is surprising there are no other published analyses of this gene in DD. The above linkage finding must also be viewed with caution in the context of the other published genome scans that have not reported linkage to this region.

\section{DYX8}

Two reports supporting the existence of a DD locus on chromosome 1 were published in 1993. Rabin et al ${ }^{69}$ reported linkage to and around the rhesus blood group CcEe antigens locus (RHCE) at 1p34-36, a region now referred to DYX8. In the same edition of the same Journal, Froster et $\mathrm{l}^{70}$ reported co-segregation between a phenotype comprising dyslexia and delayed speech and a balanced translocation $(\mathrm{t}(1 ; 2)(1 \mathrm{p} 22 ; 2 \mathrm{q} 31))$ in a single family. This suggested the presence of a DD gene at or in linkage with the breakpoints on $1 p$ or $2 q$. It should be noted that the breakpoint on $1 p$ is much more centromeric than DYX8 and the translocation should not really be viewed as supportive evidence for DYX8. However, Grigorenko et al ${ }^{71}$ and Tzenova et $\mathrm{al}^{72}$ have both reported evidence for linkage to $1 \mathrm{p}$. Grigenko et $\mathrm{al}^{70}$ found suggestive evidence of linkage to DD over a wide region of $1 \mathrm{p}$ with somewhat different patterns for different components of the phenotype (Max $\mathrm{LOD}=3.00$, single-word reading). In the study of Tzenova et $a l,{ }^{72}$ maximum evidence was found to a categorical DD phenotype $(\mathrm{NPL}=3.65)$.

\section{DYX9}

Significant evidence for linkage to Xq27 (multipoint LOD = 3.68) was observed in a genome scan in a large extended family. ${ }^{73}$ Interestingly, the locus showing greatest evidence of linkage to DD is only $12 \mathrm{cM}$ qter from a region showing evidence for linkage in a UK sample $\left(\mathrm{Xq} 26, P=0.001^{6}\right)$.

\section{Conclusions}

Family and twin studies demonstrate that genes make an important contribution to susceptibility to DD, with global measures of reading, as well as many specific component processes showing high heritability. It is now evident from molecular genetic studies that multiple genes contribute to DD with strong evidence implicating five chromosomal regions: $1 \mathrm{p}, 2 \mathrm{p}, 6 \mathrm{p}, 15 \mathrm{q}$ and $18 \mathrm{p}$, and more modest evidence supporting $6 q, 3 p, 11 p$ and Xq. In the field of complex genetic disorders, the relatively high level of consistency in linkage evidence is unusual and bodes well for gene identification approaches based upon positional cloning; indeed, there is now strong evidence for at least one novel susceptibility gene for DD on chromosome $6 \mathrm{p}$. Identifying susceptibility genes will allow us to understand the relationships between specific cognitive deficits contributing to poor reading. Understanding the biology of complex cognition is a major challenge, to which genetics can provide crucial clues. Hopefully, this new knowledge will ultimately lead to better detection and management of $\mathrm{DD}$ in people at risk.

\section{Acknowledgements}

Julie Williams and Michael O'Donovan are members of the Cardiff MRC Cooperative Group on Neuropsychiatric and Neurodegenerative Disorders (Grant No. APP1485) and are further funded by the Health Foundation for their work on developmental dyslexia (Grant No. 2263/1921), and were previously funded by the Wellcome Trust. We thank Dr Denise Harold, Natalie Cope and Michelle McDonald for their help in putting this article together.

\section{References}

1 Rasmus F, Rosens S, Dakin SC et al: Theories of developmental dyslexia: insights from a multiple case study of dyslexic adults. Brain 2003; 126: 841-865.

2 Olson RK, Forsberg H, Wise B: Genes, environment, and the development of orthographic skills; in VW Berninger (ed): The varieties of orthographic knowledge.1: Theoretical developmental issues. Dordrecht: Kluwer Academic Publishers, 1994.

3 Wolf M, Bowers PG: The double-deficit hypothesis for the developmental dyslexias. J Educ Psychol 1999; 91: 415-438.

4 Grigorenko EL, Wood FB, Meyer MS et al: Susceptibility loci for distinct components of developmental dyslexia on chromosomes 6 and 15. Am J Human Genet 1997; 60: 27-39.

5 Grigorenko EL, Wood FB, Meyer MS et al: Chromosome 6p influences on different dyslexia-related cognitive processes: further confirmation. Am J Human Gent 2000; 66: 715-723.

6 Fisher SE, Francks C, Marlow AJ et al: Independent genome-wide scans identify a chromosome 18 quantitative-trait locus influencing dyslexia. Nat Genet 2002; 30: 86-91.

7 Fisher SE, Marlow AJ, Lam J et al: A quantitative-trait locus on chromosome $6 \mathrm{p}$ influences aspects of developmental dyslexia. Am J Human Genet 1999; 64: 146-156.

8 Gayan J, Smith SD, Cherny SS et al: Quantitative-trait for specific language and reading deficits on chromosome 6p. Am J Hum Genet 1999; 64: 157-164.

9 Hinshelwood J: Four cases of congenital word-blindness occurring in the same family. Br Med J 1907; 1: 608-609.

10 Hallgren B: Specific dyslexia: a clinical and genetic study. Acta Psychiatr Neurol Scand 1950; 65 (Suppl 65): 1-287.

11 Owen F, Adams P, Forrest T et al: Learning disorders in children: sibling studies. Monographs of the society for research in child development. Child Dev 1971; 36: 1-77.

12 Yule W, Rutter M: The concept of specific reading retardation. J Child Psych Psychol 1975; 16: 181-197. 
13 Walker L, Cole E: Familiar patterns of expression of specific reading disability in a population sample. Bull Orton Soc 1965; 15: $12-24$.

14 Finucci JM, Guthrie JT, Childs AL et al: The genetics of specific reading disability. Ann Rev Hum Genet 1976; 40: 1-23.

15 Vogler GP, DeFries JC, Decker SN: Family history as an indicator of risk for reading disability. J Learning Disabil 1985; 18: $419-421$.

16 Gilger JW, Pennington BF, DeFries JC: Risk for reading disability as a function of parental history in three family studies. Reading and Writing. Reading Writing: Interdisciplinary J 1991; 3: 205-217.

17 Pennington BF: Annotation: the genetics of dyslexia. J Child Psych Psychol 1990; 31: 193-203.

18 Zerbin-Rudin E: Congenital word-blindness. Bull Orton Soc 1967; 17: $47-54$

19 Bakwin H: Reading disability in twins. Developmental medicine and child. Neurology 1973; 15: 184-187.

20 DeFries JC, Fulker DW, Labuda MC: Evidence for a genetic aetiology in reading disability of twins. Nature 1987; 329: $537-539$

21 Stevenson J, Graham P, Fredman G et al: A twin study of genetic influences on reading and spelling ability and disability. J Child Psych Psychol 1987; 28: 229-247.

22 Gayan J, Forsberg H, Olson RK: Genetic influences of subtypes of dyslexia. Behav Genet 1994; 24: 513.

23 DeFries JC, Alarcon M, Olson RC: Genetic aetiologies of reading and spelling deficits: developmental differences; in Hulme C, Snowling M (eds): Dyslexia: biology, cognition and intervention. London: Whurr, 1997, 9, 20-37.

24 Wadsworth SJ, Olson RK, Pennington BF et al: Differential genetic etiology of reading disability as a function of IQ. Behav Genet 1998; 28: 483-484.

25 Hohnen B, Stevenson J: The structure of genetic influences on general cognitive, language, phonological and reading abilities. Dev Psychol 1999; 35: 590-603.

26 Tiu Jr RD, Wadsworth SJ, Olson RK et al: Causal models of reading disability: a twin study. Twin Res 2004; 7: 275-283.

27 Knopnik VS, Alacron M, DeFries JC: Common and specific gender influences on individual differences in reading performance: a twin study. Personality Individual Differences 1998; 25: 269-277.

28 Pennington BF, Gilger JW, Pauls D et al: Evidence for major gene transmission of developmental dyslexia. J Am Med Assoc 1991; 266: 1527-1534.

29 Rutter M, Caspi A, Fergusson D et al: Sex differences in developmental reading disability. JAMA 2004; 291: 2007-2012.

30 Willcutt EG, Pennington BF, Smith SD et al: Quantitative trait locus for reading disability on chromosome $6 \mathrm{p}$ is pleiotropic for attention-deficit/hyperactivity disorder. Am J Med Genet (Neuropsychiatr Genet) 2002; 114: 260-268.

31 Smith SD, Kimberling WJ, Pennington BF et al: Specific reading disability identification of an inherited form through linkage analysis. Science 1983; 219: 1345.

32 Schulte-Korne G, Grimm T, Nothen NM et al: Evidence for linkage of spelling disability to chromosome 15. Am J Human Genet 1998; 63: $279-282$.

33 Nöthen MM, Schulte-Körne G, Grimm T et al: Genetic linkage analysis with dyslexia: evidence for linkage of spelling disability to chromosome 15. Eur Child Adolesc Psychiatry 8 1999, (Suppl3), III/56-III/59.

34 Chapman NH, Igo RP, Thomson JB et al: Linkage analyses of four regions previously implicated in dyslexia: Vonfirmation of a locus on chromosome 15q. Am J Med Genet Part B (Neuropsychiatric Genet) 2004; 131B: 67-75.

35 Bakker SC, van der Meulen EM, Buitelaar JK et al: A wholegenome scan in 164 Dutch sib pairs with attention-deficit/ hyperactivity disorder: suggestive evidence for linkage on chromosomes 7p and 15q. Am J Hum Genet 2003; 72: 1251-1260.

36 Morris DW, Robinson L, Turic D et al: Family-based association mapping provides evidence for a gene Reading Disability (RD) on chromosome 15q. Hum Mol Genet 2000; 9: 843-848.
37 Morris DW, Ivanov D, Robinson L et al: Association analysis of two candidate phospholiase genes that map to the chromosome 15q15.1-15.3 region associated with reading disability. Am J Med Genet Part B (Neuropsychiatric Genet) 2004; 129B: 97-103.

38 Marino C, Giorda R, Vanzin L et al: A locus on 15q15-15qter influences dyslexia: further support from a transmission/disequilibrium study in an Italian speaking population. I Med Genet 2004; 41: 42-46.

39 Taipale M, Kaminen N, Nopola-Hemmi J et al: A candidate gene for developmental dyslexia encodes a nuclear tetratricopeptide repeat domain protein dynamically regulated in brain. PNAS 2003; 100: 11553-11558. http//:www.pnas.org/cgi/doi/10.1073/ pnas. 1833911100.

40 Wigg KG, Couto JM, Feng Y et al: Support for EKN1 as the susceptibility locus for dyslexia on 15q21. Mol Psych 2004; 9: $1111-1121$.

41 Cope NA, Hill G, van den Bree $M$ et al: No support for association between Dyslexia Susceptibility 1 Candidate 1 and developmental dyslexia. Mol Psychiatr 2004; 10: 237-238.

42 Scerri TS, Fisher SE, Francks $C$ et al: Putative functional alleles of DYX1C1 are not associated with dyslexia susceptibility in a large sample of sibling pairs from the UK. J Med Genet 2004; 41: 853-857, Doi.10.1136/jmg.2004.018341.

43 Marino C, Giorda R, Lorusso ML et al: A family-based association study does not support DYX1C1 on $15 \mathrm{q} 21.3$ as a candidate gene in developmental dyslexia. Eur J Hum Genet 2005; 13: 491-499.

44 Smith SD, Kimberling WJ, Pennington BF: Screening for multiple genes influencing dyslexia. Reading Writing: Interdisciplinary $J$ 1991; 3: 285-298.

45 Cardon LR, Smith SD, Fulker DW et al: Quantitative trait locus for reading disability chromosome 6 . Science 1994; 266: 276-279.

46 Cardon LR, Smith SD, Fulker DW et al: Quantitative trait locus for reading disability. Science 1995; 268: 1553.

47 Marlow AJ, Fisher SE, Francks C et al: Use of multivariate linkage analysis for dissection of a complex cognitive trait. Am J Hum Genet 2003; 72: 561-570.

48 Field LL, Kaplan BJ: Absence of linkage of phonological coding dyslexia to chromosome $6 \mathrm{p} 23-\mathrm{p} 21.3$ in a large family data set. Am I Human Genet 1998; 63: 1448-1456.

49 Petryshen TL, Kaplan BJ, Liu MF et al: Absence of significant linkage between phonological coding dyslexia and chromosome $6 \mathrm{p} 23-21^{\star} 3$, as determined by use of quantitative-trait methods: confirmation of qualitative analyses. Am J Hum Genet (Neuropsychiatr Genet) 2000b; 66: 708-714.

50 Turic D, Robinson L, Duke $\mathrm{M}$ et al: Linkage disequilibrium mapping provides evidence for a gene for reading disability on chromosome 6p21.3-22. Mol Psychiatry 2003; 8: 176-185.

51 Deffenbacher KE, Kenyon JB, Hoover DM et al: Refinement of the 6p21.3 quantitative trait locus influencing dyslexia: linkage and association analyses. Hum Genet 2004; 115: 128-138.

52 Francks C, Paracchini S, Smith SD et al: A 77-kilobase region of chromosome 6p22.2 is associated with dyslexia in families from the United Kingdom and from the United States. Am J Hum Genet 2004; 75: 1046-1058.

53 Cope N, Harold D, Hill G et al: Strong evidence that KIAA0319 is a susceptibility gene for developmental dyslexia on chromosome 6p. Am J Hum Genet 2005; 76: 581-591.

54 Meng H, Smith SD, Hager $\mathrm{K}$ et al: DCDC2 is associated with reading disability and modulates neuronal development in the brain. PNAS. http//:www.pnas.org/cgi/doi/10.1073/pnas. 0508591102.

55 Schumacher J, Dahdouh F, Hilmer AM et al: Independent evidence for the VMP/DCDC2/KAAG1 gene locus on chromosomal region $6 \mathrm{p} 22$ as susceptibility factor for dyslexia. Am J Med Genet (Part B) Neuropsychicatric Genet 2005; 138B: 114.

56 Kaplan DE, Gayan J, Ahn J et al: Evidence for linkage and association with reading disability on 6p21.3-22. Am J Hum Genet 2002; 70: 1287-1298. 
57 Fagerheim T, Raeymaekers P, Tonnessen FE et al: A new gene (DYX3) for dyslexia is located on chromosome 2. J Med Genet 1999; 36: 664-669.

58 Petryshen TL, Kaplan BJ, Liu MF et al: Absence of significant linkage between phonological coding dyslexia and chromosome $6 \mathrm{p} 23-21.3$, as determined by use of quantitative-trait methods: confirmation of qualitative analyses. Am J Hum Genet 2000; 66: $708-714$.

59 Petryshen TL, Kaplan BJ, Hughes ML et al: Supportive evidence for the DYX3 dyslexia susceptibility gene in Canadian families. J Med Genet 2002; 39: 125-126.

60 Francks C, Fisher SE, Olson RK et al: Fine mapping of the chromosome 2p12-16 dyslexia susceptibility locus: quantitative association analysis and positional candidate genes SEMA4F and OTX1. Psychiatric Genet 2002; 12: 35-41.

61 Kaminen N, Hannula-Jouppi K, Kestila M et al: A genome scan for developmental dyslexia confirms linkage to chromosome 2p11 and suggests a new locus on 7q32. J Med Genet 2003; 40: $340-345$.

62 Peyrard-Janvid M, Anthoni H, Onkamo P et al: Fine mapping of the $2 \mathrm{p} 11$ dyslexia locus and exclusion of TACR1 as a candidate gene. Hum Genet 2004; 114: 510-516.

63 Petryshen TL, Kaplan BJ, Liu MF et al: Evidence for a susceptibility locus on chromosome $6 \mathrm{p}$ influencing phonological coding dyslexia. Am J Med Genet 2001; 105: 507-517.

64 Nopola-Hemmi J, Myllyluoma B, Haltia T et al: A dominant gene for developmental dyslexia on chromosome 3. J Med Genet 2001; 38: $658-664$.
65 Nopola-Hemmi J, Taipale M, Haltia T et al: Two translocations of chromosome 15q associated with dyslexia. J Med Genet 2000; 37: $771-775$

66 Stein CM, Schick JH, Taylor HG et al: Pleiotropic effects of a chromosome 3 locus on speech-sound disorder and reading. Am J Hum Genet 2004; 74: 283-297.

67 Schumacher J, Konig IR, Plume E et al: Linkage analyses of chromosomal region 18p11-q12 in dyslexia. J Neural Transm 2005, [Epub ahead of print] PMID 16075186.

68 Hsiung GY, Kaplan BJ, Petryshen TL et al: A dyslexia susceptibility locus (DYX7) linked to dopamine D4 receptor (DRD4) region on chromosome 11p15.5. Am J Med Genet 2004; 125B: 112-119.

69 Rabin M, Wen XL, Hepburn M et al: Suggestive linkage of developmental dyslexia to chromosome 1p34-p36. Lancet 1993; 342: 178.

70 Froster U, Shulte Korne G, Hebebrand J et al: Cosegregation of balanced translocation $(1 ; 2)$ with retarded speech development and dyslexia. Lancet 1993; 8864: 178-179.

71 Grigorenko EL, Wood FB, Meyer MS et al: Linkage studies suggest a possible locus for developmental dyslexia on chromosome $1 \mathrm{p}$. Am J Med Genet 2001; 105: 120-129.

72 Tzenova J, Kaplan BJ, Petryshen TL et al: Confir4mation of a dyslexia susceptibility locus on chromosome 1p34-p36 in a set of 100 Canadian Families. Am J Med Genet Part B (Neuropsychiatric Genet) 2004; 127B: 117-124.

73 de Kovel CGF, Hol FA, Heister JGAM et al: Genomewide scan identifies susceptibility locus for dyslexia on Xq27 in an extended Dutch family. J Med Genet 2004; 41: 652-657. 